УДК 321.7

\title{
ЕЛЕКТРОННА ДЕМОКРАТІЯ ЯК ІНСТРУМЕНТ ПУБЛІЧНОГО УПРАВЛІННЯ ТА АДМІНІСТРУВАННЯ: ТЕОРЕТИЧНИЙ БАЗИС
}

\author{
ELECTRONIC DEMOCRACY \\ AS A TOOL OF PUBLIC GOVERNANCE \\ AND ADMINISTRATION: THEORETICAL BASIS
}

\author{
Орловська Юлія Валеріївна \\ доктор економічних наук, профресор, \\ Придніпровська державна академія будівництва та архітектури \\ ORCID: https://orcid.org/0000-0002-5915-4261 \\ Кахович Олена Олександрівна \\ кандидат наук з державного управління, доцент, \\ Придніпровська державна академія будівництва та архітектури \\ ORCID: https://orcid.org/0000-0003-2100-1232 \\ Квактун Олеся Олексіївна \\ кандидат економічних наук, доцент, \\ Придніпровська державна академія будівництва та архітектури \\ ORCID: https://orcid.org/0000-0002-7263-8105 \\ Orlovska Yuliia, Kakhovich Olena, Kvaktun Olesia \\ Pridniprovska State Academy of Civil Engineering and Architecture
}

Проаналізовано суть терміну демократії та зміни ролі критерію просторової організації населення в інформаційному суспільстві. Підкреслено роль швидкості комунікації в соціальному світі. Досліджена можливість управління державою у віртуальному просторі Інтернету та набуття дійсної свободи та прямої демократії. Проаналізовано концептуальне підґрунтя виникнення поняття електронної демократії та виявлені особливості публічного управління в індустріальну та інфрормаційну епоху. Систематизовані основні концепції електронної демократії та здійснено порівняння їхнього змісту. Підкреслена увага політичних кіл, а не тільки наукових, до ролі інформаційно-комунікативних технологій в управлінні, в тому числі до ролі електронної демократії. Доведений ієрархічний зв'язок понять електронної демократії та електронного урядування.

Ключові слова: демократія, інфрормаційне суспільство, інформаційно-комунікаційні технології, публічне управління, пряме народовладдя, електронна демократія, електронне урядування.

Проанализированы суть термина демократии и изменения роли критерия пространственной организации населения в информационном обществе. Подчеркнута роль скорости коммуникации в социальном мире. Исследована возможность управления государством в виртуальном пространстве Интернета и получения действительной свободы и прямой демократии. Проанализировано концептуальное основание возникновения понятия электронной демократии и выявлены особенности публичного управления в индустриальную и инсрормационную эпоху. Систематизированы основные концепции электронной демократии и проведено сравнение их содержания. Подчеркнуто внимание политических кругов, а не только научных, к роли инорормационно-коммуникативных технологий в управлении, в том числе в роли электронной демократии. Доказана иерархическая связь понятий электронной демократии и электронного управления.

Ключевые слова: демократия, информационное общество, информационно-коммуникационные технологии, публичное управление, прямое народовластие, электронная демократия, электронное управление.

The essence of the term democracy and changing the role of the criterion of spatial organization of the population in the information society has been analyzed. The role of communication speed in the social world is emphasized. The possibility of governing the state in the virtual space of the Internet and gaining real freedom and direct democracy has been studied. The conceptual basis of the emergence of the concept of e-democracy is analyzed 
and the features of public administration in the industrial and information age are revealed. The basic concepts of e-democracy are systematized and their content have been compared. The concept of intellectualization of society as a leading social factor of e-democracy is characterized. The peculiarities of the concept of horizontal network connections as control channels are revealed. The existence of the previous stage of e-democracy, namely teledemocracy, has been proved. E-democracy is characterized as the use of information and communication technologies and relevant strategies by democratic actors - governments, elected officials, media, political organizations, citizens. The importance of such aspects of e-democracy as increasing the transparency of the political process; strengthening the direct involvement and participation of citizens; improving the quality of opinion-position formation by opening a new space for information and discussion, have been proved. The essence of the concept of virtual community as an opportunity of the Internet to become a tool for strengthening democratic values is analyzed. The attention of political circles, and not only scientific ones, to the role of information and communication technologies in governance, including the role of e-democracy, is emphasized. The hierarchical connection between the concepts of e-democracy and e-government has been proved.

Keywords: democracy, information society, information and communication technologies, public administration, direct democracy, e-democracy, e-government.

Постановка проблеми. Масштаби та наслідки сучасного етапу цифрровізації суспільства мають беззаперечно трансформаційний характер і породжують нові уявлення про світ. При цьому можливості електронного зв'язку та модернізація засобів передачі інсрормації змінили майже всі суспільні процеси, і не в останню чергу моделі здійснення влади. Без перебільшення можна стверджувати, що в сучасному світі відбувається Інтернет-революція, яка визначає нову систему взаємин громадян та держави.

Стрімкий розвиток електронних технологій, розповсюдження мережі Інтернет, глобальний масштаб комунікацій викликають до життя новий соціальний порядок - інфрормаційне суспільство, яке диктує нові стратегії у взаємодії влади та громадян. Зменшення часових та просторових бар'єрів, зумовлене наявністю новітніх інформаційно-комунікаційних засобів, супроводжується незнаними раніше вимогами сучасності щодо технологічного забезпечення суб'єктів публічного управління. Крім того, традиційні для світу модерну бюрократичні централізовані моделі управління демонструють нездатність реагувати на постійні зміни реальності з адекватною швидкістю та в оптимальний спосіб, що логічно приводить до необхідності пошуку нової управлінської доктрини та стратегії розвитку електронної демократії.

Аналіз останніх досліджень та публікацій. Логічно, що зазначені зміни, що торкнулись усіх аспектів соціального буття, стали предметом уважного наукового обговорення 3 боку фрілософрів, економістів, соціологів, срахівців у галузі публічного управління. Серед зарубіжних дослідників слід згадати таких відомих теоретиків, як Й. Масуда [1], Ю. Хабермас [2], А. Етціоні [3], С. Кліфтт [4], М. Гаген [5], Г. Рейнгольд [6]; на вітчизняному просторі питання е-демократії розробляли Н.В. Грицяк [7], А.В. Мєзєнцев [8], А.М. Митко [9], С.Г. Соловйов [10] та інші. Водночас додаткового дослідження потребують науково-теоретичні питання щодо з'ясування сутті френомена електронної демократії як інструменту публічного управління та адміністрування.

Формулювання цілей статті: виявлення основних підходів до пояснення явища електронної демократії в його розвитку від індустріального та інфрормаційного суспільства, а також систематизація основних концепцій електронної демократії.

Виклад основного матеріалу дослідження. Термін «демократія» (буквально влада народу, від грецьких слів demos - народ, kratos - влада, урядування) належить до числа найчастіше вживаних, зустрічається як у політичному та науковому дискурсі, так і у висловленнях авторитетних публіцистів та буденних розмовах пересічних громадян, від чого набуває досить різних смислових нюансів та відтінків; за зауваженнями дослідників, цим словом позначають і певний політичний принцип, і особливий тип влади, і систему правління, і своєрідний ідеологічний комплекс, світоглядну установку та життєвий стиль $[11$, с. 268]. У світлі досліджуваної тематики нас передусім цікавить такий аспект демократії, як організація народовладдя завдяки делегуванню більшістю населення меншості права приймати управлінські рішення, та можливі зміни в ньому в умовах інформаційного суспільства.

Дійсно, реалізація влади за традиційних умов не могла виходити безпосередньо від широких верств населення; причин тому декілька, й найбільш очевидна - це неможливість просторової організації населення в одному місці для ухвалення необхідних рішень, тим паче беручи до уваги постійну 
потребу суспільства в управлінській діяльності. Саме тому громадськість потребувала посередньої ланки в особі обраних населенням представників, що отримало назву «представницького народовладдя».

Новітні інсоормаційно-комунікативні технології, як стверджує відомий теоретик інсрормаційного суспільства М. Кастельс, вплинули навіть на такі базові характеристики буття, як простір та час. На його думку, класичне розуміння простору як певної відстані, яку можна подолати за певний відрізок часу, в мережевому контексті втрачає підстави для існування, адже завдяки Інтернету змінюються самі просторово-часові осі координат. Переміщення інформації в глобальних масштабах відбувається 3 небувалою швидкістю, і саме швидкість комунікації отримує вирішальне значення в соціальному світі [12, с. 373].

Зазначена втрата простором цілісності, його роз'єднаність та одночасна здатність до возз'єднання завдяки стрімким інфрормаційним потокам стає основою для утворення віртуального простору як сукупності соціальних мереж, що в деякому роді являють собою автономні соціальні світи [13, с. 61]. І саме створений інформаційними технологіями віртуальний простір Інтернету дозволяє громадянам брати участь в управлінні державою без необхідності передавати це своє право делегатам. Іншими словами, електронні засоби комунікації стають безпосередніми інструментами реалізації влади народом. Тут доцільно згадати відому «Декларацію незалежності кіберпростору», написану американським лібертаріанцем Дж.П. Барлоу, де Інтернет названо основою якісно нового суспільства, в якому запанують дійсна свобода та пряма демократія [14].

Одразу зазначимо, що на сьогодні ще немає підстав вести мову про остаточний перехід від представницької демократії до прямої; за словами дослідників, усі концепти електронної демократії тією чи іншою мірою будуються на теорії делегування, що означає поточну актуальність принципу представництва навіть при електронній демократії [15]. Водночас безсумнівним виглядає фракт, що цифрові технології значним чином розширюють вікна можливостей для залучення громадян до управління суспільними справами порівняно з індустріальною епохою.

Говорячи про концептуальне підґрунтя виникнення поняття електронної демократії, згадаємо думку А.М. Митко щодо ключової ролі теорії Дж. Несбіта про перехід від інду- стріального до інсрормаційного суспільства [9, с. 18]. Згідно з цією теорією, до основних характеристик інфрормаційного суспільства належать: 1) диференціація масового суспільства на малі соціальні групи за критеріями інтересів товарного та інорормаційного споживання; 2) перехід від економіки виробництва товарів до економіки послуг, поділ великих підприємств на дрібні; 3) поділ населення за родом занять, перевага менш консервативного професійно-технічного класу «білих комірців»; 4) зростання суспільної ролі теоретичного знання як джерела нововведень та політичних фрормулювань; 5) контроль технології та технологічної оцінки 3 метою збереження ресурсів для майбутнього; 6) нарешті, прийняття управлінських рішень за допомогою нової інтелектуальної технолоriï $[16$, с. 33-36].

Для зручності сприйняття та сконцентрованості інформації пропонуємо порівняльну таблицю особливостей публічного управління в індустріальному та інорормаційному суспільстві, зумовлених технологічними інноваціями (табл. 1).

Відомий японський дослідник Й. Масуда в роботі «Інфрормаційне суспільство як постіндустріальне» (1983 р.) ссрормулював основні принципи композиції майбутнього суспільства («комп'ютопії», за його термінологією), вважаючи, що основою цього соціуму буде комп'ютерна технологія 3 іï фрункцією підсилення інтелектуальної праці. На думку Масуди, інфрормаційно-комп'ютерна техніка та технологія стають новою виробничою силою й зроблять можливим масове виробництво систематизованої когнітивної інфрормації, технології і знань; провідною галуззю економіки стає інтелектуальне виробництво, продукція якого накопичуватиметься і розповсюджуватиметься через синергетичне виробництво та дольове використання, основним суб'єктом соціальної активності в новому інфрормаційному суспільстві стане «вільне співтовариство», відповідно, політичною системою - «демократія участі». Нове суспільство потенційно матиме можливість досягнути ідеальної фрорми соціальних відносин, оскільки фрункціонуватиме на підґрунті синергетичної раціональності, яка замінить принцип вільної конкуренції індустріального суспільства [17, с. 14-15].

А. Етціони запропонував концепцію «теледемократії», згідно 3 якою майбутнє сучасної демократії спирається на розвиток дистанційних засобів масової комунікації. При цьому 
Таблиця 1

Особливості публічного управління в індустріальну та постіндустріальну (інформаційну) епоху

\begin{tabular}{|l|l|l|l|l|}
\hline $\begin{array}{c}\text { Tип } \\
\text { суспільства }\end{array}$ & $\begin{array}{l}\text { Типовий суб'єкт } \\
\text { публічного } \\
\text { управління }\end{array}$ & $\begin{array}{l}\text { Вісь публічного } \\
\text { управління }\end{array}$ & $\begin{array}{l}\text { Участь громадян } \\
\text { в управлінні }\end{array}$ & \multicolumn{1}{|c|}{$\begin{array}{c}\text { Форма } \\
\text { демократії }\end{array}$} \\
\hline Індустріальне & Бюрократ & $\begin{array}{l}\text { Вертикаль } \\
\text { (ієрархія) }\end{array}$ & $\begin{array}{l}\text { Делегування } \\
\text { права ухвалювати } \\
\text { управлінські рішення }\end{array}$ & Представницька \\
\hline Інформаційне & $\begin{array}{l}\text { Громадський } \\
\text { активіст }\end{array}$ & $\begin{array}{l}\text { Горизонталь } \\
\text { (мережа) }\end{array}$ & $\begin{array}{l}\text { Участь у прийнятті } \\
\text { управлінських рішень }\end{array}$ & $\begin{array}{l}\text { Представницька, } \\
\text { пряма }\end{array}$ \\
\hline
\end{tabular}

Джерело: складено на основі [9]

він наполягав на тому, що база майбутнього демократичного устрою має перебувати не в руках профресійних політиків, а в руках спільнот. Мережеві спільноти, на відміну від традиційних ієрархічних, побудовані на інших принципах політичного управління. Їм, на думку Етціоні, притаманні такі характеристики: а) незалежність членів мережі; б) чисельність лідерів; в) добровільність зв'язків; г) загальна для всіх мета; д) декілька рівнів взаємодії [18, с. 86]. Ця теорія стає точкою відліку для теоретичної розробки електронної демократії, адже теледемократію можна повною мірою вважати попередньою формою організації народовладдя за допомогою комунікаційних засобів.

У світлі досліджуваної тематики неможливо обійти увагою теоретичні розробки відомого фрілософра XX ст. Ю. Габермаса. Розглядаючи суспільну кризу демократії та соціальні конфрлікти, притаманні постмодерному соціуму, дослідник аргументує першочергову роль комунікативних чинників у цій ситуації; на цій тезі будується його теорія комунікативної дії (дискурсу). На думку Габермаса, демократичне формування громадської думки та прийняття політичних рішень в дискурсивній моделі реалізується на теоретичних засадах етики ідеальної комунікативної ситуації в перспективі ідеальної комунікативної спільноти. Інститут публічного дискурсу, закладений на таких передумовах ідеальної комунікації, як свобода думок, рівність шансів в їх висловленні, намагання бути зрозумілим та ін., виступає як основний, у площині якого легітимуються усі інші соціальні інститути [19]. Місцем реалізації публічного дискурсу стає кіберпростір - нова громадська сорера, простір вільних обговорень актуальних суспільних проблем, у якому кожен громадянин може не лише висловитися, а й бути почутим. У такий спосіб Інтернету надається провідне місце у справі формування нових інститутів демократії завдяки виявленому взаємозв'язку між запровадженням нових інформаційних технологій і розвитком структур громадянського суспільства; виникає поняття «кібердемократія» [7, с. 10].

Вагомий внесок у розвиток теорії електронної демократії зробив М. Гаген, німецький дослідник інфрормаційного суспільства. Розроблена ним типологія е-демократії опирається на два чинники: теоретичне розуміння демократії (пряма чи посередницька ії фрорми) і технологічні засоби, що уможливлюють комунікацію. Залежно від цього вчений розрізняє такі типи, як теледемократія та кібердемократія, а також описує процес електронної демократизації.

Відправною точкою аналізу М. Гагена слугує констатація фракту, що в сучасному світі традиційні фрорми представницької демократії не відповідають вимогам часу в аспекті зростання ролі місцевого самоврядування та пріоритету прав і свобод індивіда. Внести корективи у цей стан речей можуть конкретні інформаційні технології - теле- та комп'ютерні комунікації. Теледемократія - перша фраза становлення інорормаційного суспільства; як випливає 3 назви, заснована на інорормаційних можливостях телебачення, які дозволяють організувати такі способи взаємного впливу громадськості та органів публічної влади, як інорормування, відкрите обговорення та голосування (телесронне у прямому етері).

Розвиток мережевих технологій, за М. Гагеном, сприяє процесу електронної демократизації, який передбачає не запровадження прямої демократії, а лише розвиток чинної представницької демократії та полягає у використанні електронної мережі. У такий спосіб маси отримують доступ до найважливішої інфрормації уряду, організують електронні міські зібрання, створюють об'єднання для лобіювання власних групових інтересів.

Електронна демократизація, за цією теорією, $є$ шляхом до утворення кібердемокра- 
тії - справжньої прямої демократії, яка ґрунтується на управлінській активності мережевих спільнот громадян та являє собою децентралізовану й самокеровану форму правління, в якій мінімізовані можливості зловживання владою - такі як цензура, вторгнення в приватне життя тощо - 3 боку держави [10].

Заслуговує окремого розгляду концепція британського дослідника С. Кліфта. На його думку, електронна демократія характеризується використанням інформаційних комунікаційних технологій і стратегій демократичними акторами - урядами, обраними посадовцями, медіа, політичними організаціями, громадянами (виборцями) - всередині політичних і управлінських процесів на рівні місцевих спільнот, націй та на міжнародному рівні. Для багатьох електронна демократія передбачає більшу та активнішу участь, посилену Інтернетом, мобільними комунікаціями та іншими технологіями в сучасній представницькій демократії, так само як і через більшу представницьку або пряму форму залучення громадян до вирішення суспільних питань. Електронна демократія під таким кутом зору складається 3 усіх електронних засобів комунікацій, що дають громадянам змогу докладати зусиль для вимагання від управлінців (політиків) відповідальності за їхні дії у публічній ссрері. Дослідник виокремлює такі аспекти електронної демократії, що потребують використання різних технологій: 1) підвищення транспарентності політичного процесу; 2) посилення прямого залучення і участі громадян; 3) удосконалення якості фрормування думки-позиції шляхом відкриття нового простору для інфрормації і обговорення [10].

Важливою складовою теоретико-методологічного багажу дослідження електронної демократії уявляється нам концепція Г. Рейнгольда про «віртуальне співтовариство». Вона засновується на тому, що мережі можуть стати інструментом зміцнення демократичних цінностей; сам дослідник називає Інтернет-мережу «великим зрівнювачем», здатним «вирівняти баланс влади між громадянами та політичними баронами». Ідеальною формою електронної демократії він вважав самоврядування громадян за посередництвом електронних опитувань громадської думки, без участі профресійних політичних комунікаторів, представників, посередників тощо. При цьому, на переконання автора, Інтернет стимулює розвиток публічної сорери, роблячи політичну інфрормацію доступною кожному громадянину. Крім того, мережевий підхід значною мірою трансформує державний апарат, перетворюючи ієрархічну структуру традиційної держави на мережу автономних агенцій $[20$, c. 72]. Як підсумок аналізу наведених концепції пропонуємо структурувати викладені дані у вигляді таблиці 2.

Слід сказати, що роль інфрормаційно-комунікативних технологій в управлінні ставала предметом не лише наукової, але й політичної уваги. Так, 22 липня 2000 р. лідерами країн «Великої вісімки» було прийнято Окінавську хартію глобального інформаційного суспільства, в якій оговорено ключове значення новітніх інфрормаційно-комунікаційних технологій у фрормуванні зазначеного суспільства: «Інформаційно-комунікаційні технології... є одним 3 найбільш важливих чинників, що впливають на фрормування суспільства XXI століття. Їхній революційний вплив стосується способу життя людей, їхньої освіти і праці, а також взаємодії уряду та громадянського суспільства... Стійкість глобального інфрормаційного суспільства засновується на стимулюючих розвиток людини демократичних цінностях, таких як вільний обмін інорормацією та знанням, взаємна терпимість та повага до особливостей інших людей» [21].

Зі змісту процитованого документа випливає, що саме сучасні технології сьогодні визнаються важливим фрактором демократизації.

Не можна також обійти увагою таке принципове для теорії публічного управління i адміністрування питання, як співвідношення електронної демократії та електронного урядування. Не секрет, що тематика диференціації цих понять певний час була предметом гострих наукових дискусій серед вітчизняних науковців; висловлювалися та спростовувалися думки про синонімічність зазначених термінів, мінялися погляди щодо того, яке 3 названих понять означає ціле, а яке - складовий елемент цілого, відшукувалися тотожні та відмінні риси між ними. Взагалі певним підсумком цього наукового спору можна вважати визначення, запропоновані А.В. Мєзєнцевим, згідно з якими електронна демократія являє собою «фрорму організації суспільства, де за рахунок широкого застосування інфрормаційно-комунікаційних технологій громадяни, громадські організації, представники бізнесу залучаються до прийняття державних рішень і участі в управлінні державою», а електронне урядування, відповідно, розуміється як «новітня інтерактивна система публічного управління, в основу якої закладені принципи 
Таблиця 2

Основні концепції електронної демократії

\begin{tabular}{|c|c|}
\hline $\begin{array}{c}\text { Автори } \\
\text { концепцій }\end{array}$ & Зміст концепції електронної демократії (ЕД) \\
\hline Масуда Йонедзі & $\begin{array}{l}\text { Провідний соціальний фрактор ЕД - інтелектуалізація суспільства, посилене } \\
\text { виробництво та споживання знань, що сприятиме активізації участі } \\
\text { громадськості в публічно-управлінській діяльності завдяки як підвищенню } \\
\text { відповідальності кожного за своє й суспільне життя, так і достатнього рівня } \\
\text { знань та умінь для цього в пересічного громадянина. }\end{array}$ \\
\hline Етціоні Амітай & $\begin{array}{l}\text { Акцент на трансформації управління в аспекті відмови від ієрархічних } \\
\text { принципів; орієнтація на горизонтальні, «мережеві» зв'язки як канали } \\
\text { управління та ІКТ як засоби цих зв'язків. Ввів поняття «теледемократія» } \\
\text { як фрорму організації народовладдя за допомогою телебачення, що } \\
\text { безпосередньо передує ЕД. }\end{array}$ \\
\hline $\begin{array}{c}\text { Хабермас } \\
\text { Юрген }\end{array}$ & $\begin{array}{l}\text { Центральний принцип суспільного управління - публічний дискурс, } \\
\text { безперервний діалог різних суб'єктів управління - від влади до громадян, } \\
\text { - результатом якого мають стати конкретні рішення. Комунікаційні мережі } \\
\text { - простір реалізації публічного дискурсу й головна умова трансорормації } \\
\text { демократичних інститутів. У термінологіїавтора ЕД має назву } \\
\text { «кібердемократія» і визначається як розвиток громадянського суспільства } \\
\text { завдяки запровадженню нових ІКТ. }\end{array}$ \\
\hline Гаген Мартін & $\begin{array}{l}\text { Типологія ЕД. За критеріями срорми демократії (пряма чи посередницька) } \\
\text { та виду ІКТ виділено два типи ЕД: теледемократія, що спирається } \\
\text { на телебачення, та кібердемократія, що виникає завдяки Інтернету. } \\
\text { Теледемократія характеризується як представницька демократія, } \\
\text { кібердемократія - як пряма демократія. Кібердемократія виступає радше як } \\
\text { соціальний ідеал, ніж реальний стан суспільства; нині відбувається перехід } \\
\text { від теле- до кібердемократії завдяки процесу електронної демократизації. }\end{array}$ \\
\hline Кліфрт Стівен & $\begin{array}{l}\text { Процеси управління відбуваються шляхом комунікацій між основними } \\
\text { групами акторов: урядом, обраними посадовцями, медіа, політичними } \\
\text { організаціями, громадськими організаціями та громадянами. ІКТ дають } \\
\text { змогу кожній групі знати, що відбувається в інших акторів, висловлювати } \\
\text { свою думку, вносити пропозиції та впливати на те, що відбувається. } \\
\text { Сутність ЕД - постійне підвищення активності участі громадян у прийнятті } \\
\text { управлінських рішень. }\end{array}$ \\
\hline $\begin{array}{l}\text { Рейнгольд } \\
\text { Говард }\end{array}$ & $\begin{array}{l}\text { Мережа Інтернет - головний інструмент демократії, що дозволяє } \\
\text { невладним та владним суб'єктам управління мати однакові можливості } \\
\text { та важелі впливу. Технологічні можливості роблять невладних агентів } \\
\text { управління здатними до швидкої самоорганізації для захисту своїх } \\
\text { інтересів, що наближає ЕД до прямої демократії. }\end{array}$ \\
\hline
\end{tabular}

Джерело: узагальнено на основі [7; 10; 17; 18]

відкритості, прозорості та підзвітності і яка за допомогою інфрормаційно-комунікаційних технологій забезпечує ефективну взаємодію громадян, неурядових організацій з органами державної влади» [8, с. 68].

Іншими словами, електронне урядування являє собою складовий елемент електронної демократії, який полягає у діджиталізації сервісної фрункції публічного управління, тобто завдання 3 надання органами публічного управління публічних послуг для задоволення потреб населення та захисту його інтересів. Спрощення процедур надання публічних послуг за рахунок можливості перевести хоча б частину з дій, необхідних для отримання послуги, у площину інформаційно-комунікативних технологій - приміром, звернутися із заявою про надання послуги за допомогою електронної пошти, а не шляхом особистого візиту до органу публічного управління, - ось у чому полягає головне призначення електронного урядування.

У світлі зазначеного дозволимо собі виказати певні роздуми. Інструментальне становищеелектронногоурядуваннястосовнобільш ґрунтовного ореномена електронної демократії нагадує співвідношення між двома іншими фрундаментальними категоріями - публічним управлінням та публічним адмініструванням. Як відомо, публічне адміністрування є вужчим за публічне управління поняттям, визнається складовою управління та його практичною проекцією, тобто об'єктивується як процес втілення рішень, прийнятих у системі 
публічного управління [22, с. 45]. Тому видається можливим зауваження, що електронна демократія за своєю сутністю $€$ технологічним інструментом публічного управління, тоді як електронне урядування належить до інструментарію публічного адміністрування. Зазначене, на нашу думку, дозволяє досить яскраво та наочно пояснити пов'язаність та залежність названих публічно-управлінських феноменів та додатково аргументувати необхідність їхнього розмежування.

Висновки. За результатами проведеного нами розгляду основних концептуальних підходів до розуміння ореномена електронної демократії у сучасному світі можна зробити такі висновки. По-перше, електронну демократію теоретики розуміють як нову організаційну фрорму управління суспільством, особливістю якої $є$ його здійснення за допомогою інформаційно-комунікаційних технологій. По-друге, на цю організаційну фрорму покладаються сподівання втілення ідеальної фрорми демократичного правління - так званої прямої демократії, яка не потребує передавання повноважень 3 прийняття управлінських рішень від громадян до їхніх представників у органах управління, а відбувається безпосередньо за участі самих громадян. По-третє, історичною попередницею електронної демократії виступає так звана теледемократія, де технологічним провідником-комунікатором виступають телевізійні технології.

В цілому електронна демократія як інструмент публічного управління та адміністрування може розумітися як участь громадянського суспільства в процесах прийняття управлінських рішень через мережу Інтернет, завдяки якій здійснюється розповсюдження необхідної для прийняття цих рішень інсрормації, проводяться дискусії між громадянами навколо цих відомостей, відбувається об'єднання громадян у групи відповідно до загальних інтересів та, врешті-решт, ухвалюються рішення шляхом комунікації та голосування. Можна впевнено стверджувати, що електронна демократія сьогодні являє собою найважливіший технологічний інструмент публічного управління та адміністрування, завдяки якому максимізується участь громадянського суспільства у процесах прийняття управлінських рішень і відбувається гуманізація публічного управління.

\section{СПИСОК ВИКОРИСТАНИХ ДЖЕРЕЛ:}

1. Масуда Й. Комп'ютопія / пер. з англ. В. Ляха. Філософрська і соціологічна думка. 1993. № 6. С. 36-50.

2. Хабермас Ю. Демократия. Разум. Нравственность. Москва : Academia, 1995. 252 с.

3. Этциони А. От империи к сообществу: новый подход к международным отношениям. Москва : Ладомир, 2004. $342 \mathrm{c}$.

4. Clift S. The Future of E-Democracy - The 50 Year Plan. URL: http://www.publicus.net/articles/future.html

5. Hagen M. A Typology of Electronic Democracy. URL: http://www.uni-giessen.de/fb03/vinci/labore/netz/hag_en.htm

6. Рейнгольд Г. Умная толпа: Новая социальная революция. Москва : Фаир-пресс, 2006. 416 с.

7. Грицяк Н.В., Соловйов С.Г. Електронна демократія : навч. посібник / за заг. ред. д-ра наук з держ. упр., проф. Н.В. Грицяк. Київ : НАДУ, 2015. 66 с.

8. Мєзєнцев А.В. Електронне урядування, електронна демократія - підходи до визначень. Теорія та практика державного управління. 2015. Вип. 1. С. 64-69.

9. Митко А.М. Інфрормаційна демократія: реалії та виклики часу : монограсрія. Луцьк : Вежа-друк, 2014. 400 с.

10. Соловйов С.Г. Концептуальні основи електронної демократії: зарубіжні теорії та впровадження в Україні. Державне управління: удосконалення та розвиток. 2015. № 9. URL: http://nbuv.gov.ua/UJRN/Duur_2015_9_9

11. Ильин М.В. Слова и смыслы: опыт описания ключевых политических понятий. Москва : РОССПЭН, 1997. 432 c. URL: https://www.studmed.ru/lin-m-v-slova-i-smysly-opyt-opisaniya-klyuchevyh-po-liticheskihponyatiy_5a176eabc08.html

12. Кастельс М. Информационная эпоха: экономика, общество и культура / пер. с англ.; под науч. ред. О.И. Шкаратана. Москва : ГУ ВШЭ, 2000. 608 с.

13. Назарчук А.В. Социальное время и социальное пространство в концепции сетевого общества. Вопросы фрилософии. 2012. № 9. С. 56-66.

14.Барлоу Дж.П. Декларация независимости киберпространства. URL: http://www.telecomlaw.ru/articles/ declaration.html

15. Власова О.Ю. Цифровой авторитаризм и электронная демократия: содержание и границы. Политология и право. 2020. № 3. URL: http://st-hum.ru/content/vlasova-oyu-cifrovoy-avtoritarizm-i-elektronnayademokratiya-soderzhanie-i-granicy

16. Несбит Дж. Что нас ждет в 1990-е годы. Мегатенденции. Год 2000. Десять новых направлений на 90-е годы / Дж. Несбит, П. Эбурдин ; пер. с англ. Москва, 1992. 415 с. 
17. Штанько В.І., Бордюгова Т.Г. Інфрормаційне суспільство: соціально-фрілософрські проблеми становлення : навч. посібник. Харків : ХНУРЕ, 2012. 172 с.

18. Ровинская Т. Электронная демократия в теории и на практике. Мировая экономика и международные отношения. 2013. № 12. С. 84-96.

19. Марчук В.П. Особливості формування суспільних цінностей в комунікативних теоріях Ю. Габермаса та K.-O. Апеля. Філософрські проблеми гуманітарних наук : зб. наук. праць. URL: http://www.info-library.com.ua/ books-text-11385.html

20.Быков И.А. «Электронная демократия» vs «электронное правительство»: концептуальное противостояние. Политическая экспертиза: ПОЛИТЭКС. 2005. Вып. 3. С. 69-79.

21. Окинавская хартия глобального информационного общества: международный документ от 22 июля 2000 года. URL: https://ifap.ru/ofdocs/rest/okinhar.htm

22. Колесникова К.О. Публічне адміністрування в Україні: огляд літературних джерел. Теорія та практика державного управління. 2013. Вип. 3. С. 41-45.

\section{REFERENCES:}

1. Masuda Y. (1993). Kompiutopiia / per. z anhl. V. Liakha. Filosofska i sotsiolohichna dumka, no. 6, pp. 36-50.

2. Habermas Yu. (1995). Demokratiya. Razum. Nravstvennost. Moscow: Academia, 252 p.

3. Ettsioni A. (2004). Ot imperii k soobschestvu: novyiy podhod k mezhdunarodnyim otnosheniyam. Moscow: Ladomir, $342 \mathrm{p}$.

4. Clift S. The Future of E-Democracy - The 50 Year Plan. URL: http://www.publicus.net/articles/future.html

5. Hagen M. A Typology of Electronic Democracy. URL: http://www.uni-giessen.de/fb03/vinci/labore/netz/hag_en.htm

6. Reyngold G. (2006). Umnaya tolpa: Novaya sotsialnaya revolyutsiya. Moscow: Fair-press, 416 p.

7. Hrytsiak N.V., Soloviov S.H. (2015). Elektronna demokratiia : navch. posibnyk / za zah. red. d-ra nauk z derzh. upr., prof. N.V. Hrytsiak. Kyiv: NADU, 66 p.

8. Miezientsev A.V. (2015). Elektronne uriaduvannia, elektronna demokratiia - pidkhody do vyznachen. Teoriia ta praktyka derzhavnoho upravlinnia, no. 1, pp. 64-69.

9. Mytko A.M. (2014). Informatsiina demokratiia: realii ta vyklyky chasu: monohrafiia. Lutsk: Vezha-druk, 400 p.

10. Soloviov S.H. (2015). Kontseptualni osnovy elektronnoi demokratii: zarubizhni teorii ta vprovadzhennia v Ukraini. Derzhavne upravlinnia: udoskonalennia ta rozvytok, no. 9. URL: http://nbuv.gov.ua/UJRN/Duur_2015_9_9

11. Ilin M.V. (1997). Slova i smyislyi: opyit opisaniya klyuchevyih politicheskih ponyatiy. Moscow: ROSSPEN, 432 p. URL: https://www.studmed.ru/lin-m-v-slova-i-smysly-opyt-opisaniya-klyuchevyh-po-liticheskih-ponyatiy_5a176eabc08.html

12. Kastels M. (2000). Informatsionnaya epoha: ekonomika, obschestvo i kultura / per. s angl.; pod nauch. red. O.I. Shkaratana. Moscow: GU VShE, 608 p.

13. Nazarchuk A.V. (2012). Sotsialnoe vremya i sotsialnoe prostranstvo v kontseptsii setevogo obschestva. Voprosyi filosofii, no. 9, pp. 56-66.

14. Barlou Dzh.P. Deklaratsiya nezavisimosti kiberprostranstva. URL: http://www.telecomlaw.ru/articles/declaration.html

15. Vlasova O.Yu. (2020). Tsifrovoy avtoritarizm i elektronnaya demokratiya: soderzhanie i granitsyi. Politologiya i pravo, no. 3. URL: http://st-hum.ru/content/vlasova-oyu-cifrovoy-avtoritarizm-i-elektronnaya-demokratiya-soderzhanie-i-granicy

16. Nesbit Dzh. (1992). Chto nas zhdet v 1990-e godyi. Megatendentsii. God 2000. Desyat novyih napravleniy na 90-e godyi / Dzh. Nesbit, P. Eburdin ; per. s angl. Moscow, 415 p.

17. Shtanko V.I., Bordiuhova T.H. (2012). Informatsiine suspilstvo: sotsialno-filosofski problemy stanovlennia: navch. posibnyk. Kharkiv: KhNURE, 172 p.

18. Rovinskaya T. (2013). Elektronnaya demokratiya v teorii i na praktike. Mirovaya ekonomika i mezhdunarodnyie otnosheniya, no. 12, pp. 84-96.

19. Marchuk V.P. Osoblyvosti formuvannia suspilnykh tsinnostei v komunikatyvnykh teoriiakh Yu. Habermasa ta K.-O. Apelia. Filosofski problemy humanitarnykh nauk: zb. nauk. prats. URL: http://www.info-library.com.ua/bookstext-11385.html

20. Byikov I.A. (2005). «Elektronnaya demokratiya» vs «elektronnoe pravitelstvo»: kontseptualnoe protivostoyanie. Politicheskaya ekspertiza: POLITEKS, no. 3, pp. 69-79.

21. Okinavskaya hartiya globalnogo informatsionnogo obschestva: mezhdunarodnyiy dokument ot 22 iyulya 2000 goda. URL: https://ifap.ru/ofdocs/rest/okinhar.htm

22. Kolesnykova K.O. (2013). Publichne administruvannia v Ukraini: ohliad literaturnykh dzherel. Teoriia ta praktyka derzhavnoho upravlinnia, no. 3, pp. 41-45. 